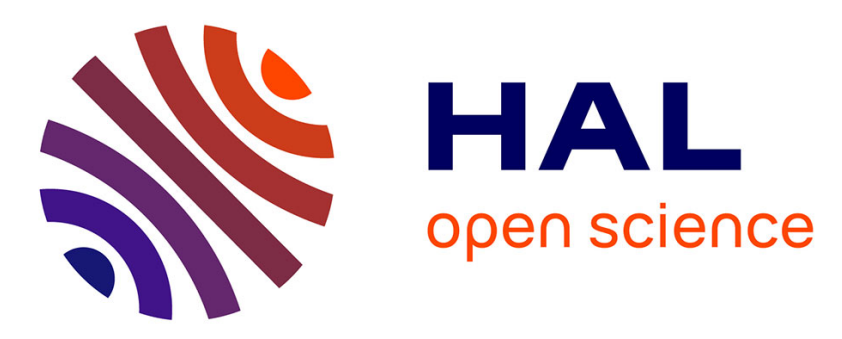

\title{
Evaluation of pituitary function after traumatic brain injury in childhood
}

Sophie N Khadr, Patricia M Crofton, Patricia Jones, Barbara Wardhaugh, Jennifer Roach, Amanda Drake, Robert Minns, Christopher J H Kelnar

\section{- To cite this version:}

Sophie N Khadr, Patricia M Crofton, Patricia Jones, Barbara Wardhaugh, Jennifer Roach, et al.. Evaluation of pituitary function after traumatic brain injury in childhood. Clinical Endocrinology, 2010, 73 (5), pp.637. 10.1111/j.1365-2265.2010.03857.x . hal-00561819

\section{HAL Id: hal-00561819 https://hal.science/hal-00561819}

Submitted on 2 Feb 2011

HAL is a multi-disciplinary open access archive for the deposit and dissemination of scientific research documents, whether they are published or not. The documents may come from teaching and research institutions in France or abroad, or from public or private research centers.
L'archive ouverte pluridisciplinaire HAL, est destinée au dépôt et à la diffusion de documents scientifiques de niveau recherche, publiés ou non, émanant des établissements d'enseignement et de recherche français ou étrangers, des laboratoires publics ou privés. 


\section{CLINICAL ENDOCRINOLOGY}

\section{Evaluation of pituitary function after traumatic brain injury in childhood}

\begin{tabular}{|r|l|}
\hline Journal: & Clinical Endocrinology \\
\hline Manuscript ID: & CEN-2010-000246.R2 \\
\hline Manuscript Type/Office: & 1 Original Article - UK/Europe \\
\hline Date Submitted by the & 25 -Jul-2010 \\
\hline Complete List of Authors: & $\begin{array}{l}\text { Khadr, Sophie; UCL Institute of Child Health, General \& Adolescent } \\
\text { Paediatrics } \\
\text { Crofton, Patricia; Royal Hospital for Sick Children Edinburgh, } \\
\text { Paediatric Biochemistry } \\
\text { Jones, Patricia; University of Edinburgh, Section of Child Life and } \\
\text { Health } \\
\text { Wardhaugh, Barbara; Royal Hospital for Sick Children Edinburgh, } \\
\text { Paediatric Endocrinology } \\
\text { Roach, Jennifer; Royal Hospital for Sick Children Edinburgh, } \\
\text { Paediatric Endocrinology } \\
\text { Drake, Amanda; University of Edinburgh, Section of Child Life and } \\
\text { Health } \\
\text { Minns, Robert; University of Edinburgh, Section of Child Life and } \\
\text { Health } \\
\text { Kelnar, Christopher; University of Edinburgh, Section of Child Life } \\
\text { and Health }\end{array}$ \\
\hline \hline Key Words: & $\begin{array}{l}\text { Hypopituitarism < Conditions: < Pituitary, Growth hormone < } \\
\text { Hormones/related: < Pituitary, Pituitary function tests < } \\
\text { Investigations \& Rx: < Pituitary, Childhood }\end{array}$ \\
\hline \hline
\end{tabular}

\section{SCHOLARONE $^{\text {TH }}$ Manuscripts}


Title: Evaluation of pituitary function after traumatic brain injury in childhood

Short title: Pituitary dysfunction after head injury in childhood

\author{
Authors: Sophie N. Khadr ${ }^{1}$, Patricia M. Crofton ${ }^{2}$, Patricia A. Jones ${ }^{1}$, Barbara Wardhaugh ${ }^{2}$, \\ Jennifer Roach ${ }^{2}$, Amanda J. Drake ${ }^{1}$, Robert A. Minns ${ }^{1}$, Christopher J. H. Kelnar ${ }^{1}$ \\ ${ }^{1}$ Section of Child Life \& Health, University of Edinburgh \\ ${ }^{2}$ Royal Hospital for Sick Children Edinburgh
}

The research was conducted in the Dept. of Child Life and Health, University of Edinburgh.

\title{
Correspondence:
}

Dr. Sophie Khadr

General and Adolescent Paediatrics Unit

UCL Institute of Child Health

30 Guilford St.

London WC1N 3EH

Tel.: 07779781371

Fax: 02073809064

Email: s.khadr@ich.ucl.ac.uk

Keywords: Traumatic Brain Injury, Hypopituitarism, Growth Hormone, Childhood, Adolescent.

Conflicts of interest: None.

Financial disclosure: The research was supported by a grant from Novo Nordisk. 
Word Count: 3,408 excluding title page, abstract and references.

\begin{tabular}{ll}
\multicolumn{2}{l}{ List of abbreviations: } \\
BMI & Body mass index \\
CT & Computerised tomography \\
GCS & Glasgow Coma Scale \\
GHD & Growth hormone deficiency \\
HPA & Hypothalamic-pituitary-adrenal \\
ISS & Injury Severity Score \\
ITT & Insulin tolerance test \\
KOSCHI & King's Outcome Scale for Childhood Head Injury \\
SDS & Standard deviation score \\
TBI & Traumatic brain injury
\end{tabular}




\begin{abstract}
\end{abstract}
Objectives: Post-traumatic hypopituitarism is well described among adult traumatic brain injury survivors. We aimed to determine the prevalence and clinical significance of pituitary dysfunction after head injury in childhood.

Design: Retrospective exploratory study.

Patients: 33 survivors of accidental head injury (27 males). Mean (range) age at study was 13.4y (5.4-21.7y) and median (range) interval since injury, 4.3y (1.4-7.8y). Functional outcome at study: 15 good recovery, 16 moderate disability, two severe disability.

Measurements: Early morning urine osmolality and basal hormone evaluation were followed by the $\mathrm{GnRH}$ and insulin tolerance $(\mathrm{n}=25)$ or glucagon tests (if previous seizures, $\mathrm{n}=8$ ). Subjects were not primed. Head injury details were extracted from patient records.

Results: No subject had short stature (mean height SD score +0.50 , range -1.57 to +3.00 ). Sub-optimal GH responses $(<5 \mu \mathrm{g} / \mathrm{L}$ ) occurred in six peri-pubertal males (one with slow growth on follow-up) and one post-pubertal male (peak GH $3.2 \mu \mathrm{g} / \mathrm{L}$ ). Median peak cortisol responses to insulin tolerance or glucagon tests were 538 and $562 \mathrm{nmol} / \mathrm{L}$. 9/25 and 2/8 subjects had sub-optimal responses respectively, two with high basal cortisol levels. None required routine glucocorticoid replacement. In three, steroid cover was recommended for moderate/severe illness or injury. One male was prolactin deficient. Other basal endocrine results and GnRH-stimulated LH and FSH were appropriate for age, sex and pubertal stage. Abnormal endocrine findings were unrelated to the severity or other characteristics of TBI, or functional outcome.

Conclusions: No clinically significant endocrinopathy was identified amongst survivors of accidental childhood TBI, although minor pituitary hormone abnormalities were observed. 


\section{Introduction}

The hypothalamus and pituitary are vulnerable to vascular and mechanical injury as a consequence of trauma. ${ }^{1}$ Cross-sectional and prospective longitudinal studies have reported long-term hypopituitarism in between $11 \%$ and $69 \%$ of adult traumatic brain injury (TBI) survivors. ${ }^{2}$ Whilst many early endocrine abnormalities resolve within months of injury, others may emerge later. ${ }^{2}$ Growth hormone deficiency (GHD) is commonest, reported in between $10 \%$ and $38 \%$ of subjects. ${ }^{2}$ In a recent meta-analysis, ${ }^{3}$ the pooled prevalence of anterior pituitary dysfunction $\geq$ five months after adult TBI was $27 \%$. Early data suggest that post-traumatic hypopituitarism may impair physical rehabilitation and functional outcome after TBI. ${ }^{4}$ Consensus guidelines recommend screening adult TBI survivors for pituitary dysfunction, ${ }^{5}$ including GH stimulation testing $\geq 12$ months after injury. ${ }^{6}$

Post-traumatic hypopituitarism has been reported in preliminary paediatric TBI studies. ${ }^{7,8}$ However, there is limited understanding of the likelihood, causative mechanisms and significance of pituitary dysfunction in this group. We report a retrospective exploratory study investigating the prevalence and clinical significance of post-traumatic hypopituitarism amongst a cohort of childhood TBI survivors. We hypothesised that clinically significant pituitary dysfunction would be as prevalent among children as in adults. We also aimed to identify any head injury characteristics associated with post-traumatic hypopituitarism.

\section{Subjects \& Methods}

\section{$\underline{\text { Subjects }}$}

The study population comprised subjects with previous accidental TBI, aged $<16$ years at injury and admitted to Edinburgh hospitals between $1^{\text {st }}$ January 2001 and $31^{\text {st }}$ August 2007. Inclusion criteria were 1) significant head injury, defined as (a) moderate or severe TBI, or (b) minor TBI with injuries incurring an Injury Severity Score (ISS) $\geq 16$ (see below); and 2) a minimum interval of 12 months between head injury and study entry. Exclusion criteria 
Age at injury was obtained from subjects' medical records. We used post-resuscitation Glasgow Coma Scale (GCS) scores to grade TBI severity. Minor, moderate and severe TBI were defined respectively as head trauma with post-resuscitation GCS scores of 13-15, 9-12 and $<9 .{ }^{10}$ The ISS is an anatomical scoring system providing a score from 0-75 for patients with multiple injuries. ${ }^{11}$ An ISS score of $\geq 16$ was chosen to enable inclusion of 'minor' TBI subjects with extradural or subdural haemorrhages who were intubated and ventilated for neurosurgery before their GCS score fell below 13 .

We reviewed subjects' cranial computerised tomography (CT) scans to identify injuries that might be associated with pituitary dysfunction. The Marshal CT score ${ }^{12}$ was used to grade diffuse brain injury. We documented any evidence of intra-cerebral oedema ( \pm midline shift) on imaging and any history of post-traumatic seizures.

\section{Clinical assessment at study}

A medical history was taken from each subject. We evaluated functional outcome after TBI using the King's Outcome Scale for Childhood Head Injury (KOSCHI). ${ }^{13}$ Height and weight 
were measured and used to determine body mass index (BMI). Parent-reported parental heights were also recorded. We determined standard deviation scores (SDS) for anthropometric measurements using the Pfizer International Growth Database (KIGS) Auxology Calculator (Pfizer Endocrine Care ${ }^{\mathrm{TM}}$ ). This uses Tanner/Whitehouse reference data for height and height velocity ${ }^{14}$ and the British 1990 standards produced by the LMS method for weight and BMI. ${ }^{15,16}$ We performed Tanner pubertal staging ${ }^{14}$ where clinically indicated, with subjects' consent. Subjects were grouped into three categories: pre-puberty (stage B1 in girls, or G1 in boys with testicular volumes $<4 \mathrm{~mL}$ ), early/mid-puberty (B2-3 in girls or G2-3 in boys) and late/post-puberty (B4-5 in girls or G4-5 in boys).

\section{$\underline{\text { Endocrine assessment }}$}

Each subject fasted from 24:00h the night before and provided an early morning urine sample for osmolality at assessment. A basal (08:00-10:00h) blood sample was obtained for plasma cortisol, IGF1, TSH, free T4, prolactin, urea, electrolytes, creatinine and osmolality.

We measured GH and cortisol responses to stress using the insulin tolerance test (ITT) as first-line or the glucagon test in subjects with previous seizures. Peri-pubertal subjects were not primed with sex steroids before testing. In both tests, baseline samples were obtained for serum $\mathrm{GH}$, cortisol and laboratory glucose at -30 minutes and time 0 . For the ITT, short acting insulin was administered intravenously at time 0 at a dose determined by the baseline point-of-care glucose meter reading: $4.0-4.5 \mathrm{mmol} / \mathrm{L}, 0.1 \mathrm{u} / \mathrm{kg} ;>4.5 \mathrm{mmol} / \mathrm{L}, 0.15 \mathrm{u} / \mathrm{kg}$. Further blood samples for GH, cortisol and meter and laboratory glucose were taken at 20, 30, 60 and 90 minutes post-injection. Subjects received a glucose-containing drink after achieving adequate hypoglycaemia (blood glucose $\leq 2.2 \mathrm{mmol} / \mathrm{L}$ ). For the glucagon test, 20 $\mu \mathrm{g} / \mathrm{kg}$ (maximum $1 \mathrm{mg}$ ) of glucagon was administered intramuscularly at time 0. Blood samples for GH, cortisol and meter and laboratory glucose were taken at 20, 60, 90, 120, 150 and 180 minutes. 
LH and FSH responses to stimulation were evaluated using the low-dose GnRH test. ${ }^{17} \mathrm{We}$ collected blood samples for LH, FSH and oestradiol or testosterone at time 0. Further samples for LH and FSH were obtained at 20 and 60 minutes post-intravenous injection of 10 $\mu \mathrm{g}$ of GnRH.

\section{$\underline{\text { Analytical methods }}$}

Urea, creatinine, electrolytes, osmolality and glucose were measured by standard laboratory methods. All hormones were measured by automated chemiluminescent immunoassays. Free T4, TSH and oestradiol were measured using the Architect analyzer (Abbott Diagnostics, Maidenhead, UK). Respective coefficients of variation were $<6 \%,<3 \%$ and $14 \%$ (at 70 pmol/L oestradiol). LH, FSH, prolactin, cortisol and testosterone were measured using the ADVIA Centaur analyzer (Siemens Healthcare Diagnostics UK). Coefficients of variation were $<3 \%,<3 \%,<5 \%,<6 \%$ and $<9 \%$ respectively. GH was measured using an immunoassay calibrated against IS 98/574 on the Immulite 2000 analyzer (Siemens Healthcare Diagnostics UK) with a coefficient of variation of $<5 \%$. IGF1 levels were measured by a two-site immunoenzymometric assay (OCTEIA IGF1) supplied by Immunodiagnostic Systems Ltd, Tyne and Wear, UK, with a coefficient of variation of $<11 \%$.

\section{$\underline{\text { Interpretation of endocrine test results }}$}

We interpreted IGF1 concentrations in relation to age- and sex-related reference ranges determined for the Nichols Advantage assay (Nichols Institute Diagnostics, San Clemente, California, USA), ${ }^{18}$ which gave good agreement with the OCTEIA assay used in this study (M. Wallace, personal communication). Other basal results were interpreted using locally established paediatric reference ranges.

We defined an adequate peak GH response to insulin-induced hypoglycaemia or glucagon as $>5 \mu \mathrm{g} / \mathrm{L}$. The ITT cut-off was established locally using data from Scottish children and the Immulite $2000 \mathrm{GH}$ assay. The same cut-off was used for the glucagon test. We used locally 
determined age-dependent cut-offs to evaluate peak cortisol response to the ITT: $\geq 470 \mathrm{nmol} / \mathrm{L}$ in subjects $\geq 10$ years; $\geq 550 \mathrm{nmol} / \mathrm{L}$ in subjects $<10$ years. ${ }^{19}$ A cut-off of $450 \mathrm{nmol} / \mathrm{L}$ was used to define an adequate peak cortisol response to glucagon. ${ }^{20}$ We evaluated peak LH and FSH responses to the low-dose GnRH test using locally determined reference data. ${ }^{17}$

\section{$\underline{\text { Statistical analysis }}$}

Continuous data were expressed as mean (range) if Gaussian or median (range) if nonGaussian. Comparisons between groups were performed using the two-sample t-test or the Mann-Whitney U test as appropriate. The Chi-squared or Fisher's exact tests were used to compare categorical data. Statistical comparisons were performed using Minitab version 14.

\section{Results}

The study population comprised 154 subjects aged $<16$ years at injury. One hundred and thirty-three met eligibility criteria. One hundred and two subjects were invited to enter the study (77\%); reasons for exclusion are listed in Figure 1. Thirteen subjects with GCS scores of 13-15 were excluded despite small subdural or extradural haemorrhages with an ISS of 16 because they remained clinically well and did not require mechanical ventilation or neurosurgery. We concluded that the benign clinical course did not justify invasive testing. Nine others with extradural haemorrhages were excluded because head injury severity and clinical course were unclear from computer records and case records were unavailable. Thirty-four subjects consented to enter the study but tests were cancelled in one case because secure venous access could not be established. Hence, results are available for 33 subjects.

We compared characteristics of recruited subjects with those of the wider cohort to determine how representative our sample was. Males comprised $76 \%$ of recruited subjects and $76 \%$ of all eligible subjects. Mean age at injury was similar in invited (9.5y), uninvited (9.7y), recruited $(9.2 \mathrm{y})$ and non-recruited subjects $(9.6 \mathrm{y}$, all $\mathrm{p} \geq 0.6)$. Mean age at study was 
comparable between recruited and non-recruited subjects: 13.4 (5.4-21.7) vs. 13.5 (2.0-21.0) years $(\mathrm{p}=0.9)$. More subjects with minor TBI (5/33 vs. 5/69) and fewer with severe TBI (12/33 vs. 31/69) were recruited than not, but differences were not statistically significant $(\mathrm{p}=0.2)$.

\section{$\underline{\text { Sample characteristics }}$}

Characteristics of recruited subjects are summarised in Table 1. No subject had clinical evidence of short stature or abnormal pubertal development. Mean height, weight and BMI SDS were comparable and within population norms. Target height and parental-adjusted height values were within \pm 2.0 SD for all but one subject (data not shown). One child was on long-term (supra-physiological) corticosteroid therapy for an unrelated medical condition (omitted on the day of testing); two others were prescribed low-dose inhaled steroids for asthma.

\section{Endocrine evaluation}

Pituitary hormone abnormalities were identified in 13 of 33 subjects (39\%), involving two hormone axes in four subjects (12\%). Further details are provided below and in Table 2.

Basal hormones: There was no evidence of diabetes insipidus from paired early morning urine and plasma osmolalities $(n=32)$. No subject had central hypothyroidism. TSH was mildly raised in one child $(5.2 \mathrm{mU} / \mathrm{L}$, reference range $0.5-4.2 \mathrm{mU} / \mathrm{L})$, raising the possibility of an unrelated thyroid disorder. Repeat testing was advised in six months. One male subject was prolactin deficient $(<50 \mathrm{mU} / \mathrm{L}$, reference range $60-500 \mathrm{mU} / \mathrm{L})$. Two subjects had mildly reduced IGF1 concentrations for age and pubertal stage: $146 \mu \mathrm{g} / \mathrm{L}$ at 12.6 years and $179 \mu \mathrm{g} / \mathrm{L}$ at 14.8 years (reference ranges $150-600 \mu \mathrm{g} / \mathrm{L}$ and $200-650 \mu \mathrm{g} / \mathrm{L}$ for ages $11-14$ years and $14-$ 17 years respectively). The first had a normal GH response to the ITT; the other's response was suboptimal (peak GH $2.8 \mu \mathrm{g} / \mathrm{L}$; subject 9, Table 2). 
Hypothalamo-pituitary-gonadal axis: Basal oestradiol or testosterone and peak LH and FSH responses to $\mathrm{GnRH}$ were appropriate for age, sex and pubertal stage in all subjects.

HPA axis: Median basal cortisol was 298 (110-722) nmol/L (reference range 06:00h-10:00h: 150-600 nmol/L). Levels were slightly low in two subjects (110 and $146 \mathrm{nmol} / \mathrm{L})$. Twentyfive subjects underwent an ITT, and eight, the glucagon test (all with previous seizures). Plasma glucose fell to $\leq 2.2 \mathrm{mmol} / \mathrm{L}$ in all subjects undergoing an ITT. Median peak cortisol was $538(367-717) \mathrm{nmol} / \mathrm{L}$ during the ITT and 562 (289-729) nmol/L during the glucagon test. Peak cortisol responses to the ITT were suboptimal in nine subjects (Figure 2A), including the two with low basal cortisol levels (see above). Two were on low-dose inhaled steroids; the subject on high-dose steroid therapy had a normal cortisol response to stimulation. Five of nine had only borderline low responses (within $50 \mathrm{nmol} / \mathrm{L}$ below the cutoff) requiring no treatment. In three others, peak cortisol response was between 50 and 100 nmol/L below the cut-off and steroid cover was recommended during moderate or severe illness or injury. The ninth had a high basal cortisol ( $624 \mathrm{nmol} / \mathrm{L})$. Two of eight subjects had flat cortisol responses to glucagon. In one case, basal cortisol concentration was high (722 nmol/L). The other subject (subject 8 , Table 2) declined further evaluation of the HPA axis; no treatment was recommended.

GH axis: Median peak GH response to stimulation was $7.9(2.5-25.4) \mu \mathrm{g} / \mathrm{L}$. Seven males had sub-optimal peak GH responses $(<5 \mu \mathrm{g} / \mathrm{L})$ to the ITT $(\mathrm{n}=6)$ or glucagon $(\mathrm{n}=1)$ (Figure $2 \mathrm{~B})$. Six were in late pre-puberty or early to mid-puberty. All had height SDS within the range 1.52 to 1.38 . Four of these had normal height velocities in relation to pubertal stage at follow-up (>-0.8 SD in all cases); in the fifth (subject 9, Table 2), growth velocity was inappropriately slow and GH was prescribed. The sixth failed to attend two follow-up appointments. The seventh subject (subject 3, Table 2) was post-pubertal, with a borderline low GH response to the ITT $(3.2 \mu \mathrm{g} / \mathrm{L}$, height SDS -0.93). Consensus guidelines variously use cut-offs of $<3 \mu \mathrm{g} / \mathrm{L}^{21}$ or $<5 \mu \mathrm{g} / \mathrm{L}$ to the ITT $^{22}$ to define GHD in adolescence. 
Anthropometry in relation to GH status:

We excluded results for the subject on supra-physiological corticosteroid therapy. Comparisons were made between subjects with normal (n=25) and suboptimal $(n=7)$ GH responses to stimulation testing. There were no significant differences in SDS between normal and abnormal groups with respect to median height ( 0.56 vs. $0.75, \mathrm{p}=0.7)$, weight (0.57 vs. $1.20, \mathrm{p}=0.5)$ or $\mathrm{BMI}(0.52$ vs. $1.30, \mathrm{p}=0.1)$.

Hormone outcome in relation to head injury characteristics:

Subjects with normal $(n=20)$ and abnormal $(n=13)$ endocrine results were similar with respect to: mean age at injury (9.2y vs. $9.3 \mathrm{y}, \mathrm{p}=0.9)$, age at study $(13.5 \mathrm{y}$ vs. $13.2 \mathrm{y}, \mathrm{p}=0.9)$, interval since TBI ( $4.3 y$ vs. $3.9 y, p=0.5)$, and TBI severity $(p=0.3)$. Nine of $12(75 \%)$ survivors of severe TBI had normal pituitary function.

No subject had radiographic evidence of hypothalamo-pituitary injury. Eight subjects had no visible intracranial pathology on CT scan, of whom five had endocrine abnormalities. The only subject with a diencephalic injury (a thalamic haemorrhage) had a suboptimal peak GH response to the ITT (3.2 $\mu \mathrm{g} / \mathrm{L}$; subject 3, Table 2). Both subjects with diffuse axonal injury had normal endocrine function. Similar proportions of subjects in both endocrine outcome groups had sustained a basal skull fracture, frontal lobe injury, extra-axial haemorrhage or intra-parenchymal clot or contusion, developed intra-cerebral oedema \pm midline shift on CT scan, or suffered post-traumatic seizures (all $\mathrm{p} \geq 0.3$ ). There was no evidence of an association between a Marshall CT score $>1$ and pituitary dysfunction $(\mathrm{p}=0.2)$.

In the two subjects who were severely disabled at study, one had normal and one, abnormal pituitary function (subject 3, Table 2). In the moderately disabled group, ten had normal pituitary function and six had pituitary hormone abnormalities. 


\section{Discussion}

This cross-sectional study examined the prevalence of pituitary dysfunction in a cohort of British childhood TBI survivors. We observed pituitary hormone abnormalities in 13/33 subjects (39\%), affecting two axes in four cases. However, none were unequivocally clinically significant.

Eleven subjects had suboptimal cortisol responses to stimulation, discounted in two because pre-test cortisol levels were high, indicating normal HPA function. Although a further two were on inhaled steroid therapy, the low doses made adrenal suppression unlikely. Rather, our results raise the question of stimulation test reproducibility. Peak cortisol responses to the ITT are reproducible in healthy adults but there may be within-subject variability in patients with subtle HPA dysfunction. ${ }^{23}$ Few with severe ACTH deficiency are misclassified. ${ }^{23}$ Two of our subjects with suboptimal cortisol responses had undergone the glucagon test, which is known to elicit a poor cortisol response in approximately $10 \%$ of healthy individuals. ${ }^{20}$ No subject had symptoms or a low enough peak cortisol response to suggest severe ACTH deficiency. Partial HPA insufficiency is poorly defined and approaches to treatment vary widely. ${ }^{24}$ Under normal (unstressed) physiological conditions, such patients have a cortisol day curve similar to controls ${ }^{25,26}$ and conventional hydrocortisone replacement regimens may be excessive. We recommended hydrocortisone cover during illness for three subjects.

Most (6/7) of our low GH responses to the ITT could be due to peri-pubertal blunting. These subjects showed no evidence of growth impairment at assessment and remain under review. We initiated GH therapy in one, in whom height velocity at follow-up was inappropriately slow for pubertal stage despite findings consistent with resolving constitutional delay of growth and puberty. We will reassess the GH axis off treatment at adult height. The decision not to prime peri-pubertal subjects with exogenous sex steroids prior to GH stimulation testing contrasted with our normal clinical practice. Asking subjects to attend the research 
centre for pubertal staging several days before their endocrine assessment would have been difficult for families coming from afar. Priming can temporarily reverse physiological blunting of GH secretion in late pre-, early or delayed puberty, helping to discriminate between normal and abnormal GH status in short children. ${ }^{27}$ However, there is no consensus on its use in clinical practice. ${ }^{28}$

We used the same peak GH cut-off for the ITT and glucagon tests. Adult studies have reported similar peaks in both tests. ${ }^{29} \mathrm{GH}$ responses to stimulation are a continuum and are poorly reproducible. ${ }^{30}$ Although our locally derived cut-off $(5 \mu \mathrm{g} / \mathrm{L})$ is lower than the commonly used value of $7 \mu \mathrm{g} / \mathrm{L}$, many studies have questioned the validity of this arbitrary value,${ }^{31}$ different assays may give widely differing results for $\mathrm{GH},{ }^{32}$ and responses to the ITT may depend on how the test is performed. ${ }^{33}$ Hence, GH cut-offs should be defined for each assay, laboratory and local reference population..$^{30}$ Niederland et al. ${ }^{8}$ diagnosed GHD in $42 \%$ (11/26) of childhood TBI survivors using the $7 \mu \mathrm{g} / \mathrm{L}$ cut-off for the ITT and L-dopa tests but, as in our study, found no significant difference in height SDS between subjects with normal and abnormal responses.

Prolactin deficiency, observed in one subject with a borderline suboptimal cortisol response to the ITT but no other pituitary abnormality, is of little clinical significance in males. Often associated with severe hypopituitarism, it has been reported in one other TBI study. ${ }^{34}$

In contrast to two other paediatric studies, ${ }^{7,9}$ we evaluated pituitary function fully in all our subjects. Poomthavorn et al. detected hormone abnormalities in $17 \%$ of severe TBI survivors but only half underwent baseline testing and only $8 / 54$, stimulation testing. ${ }^{7}$ Selection bias may have been increased by including results from four children found to have hypopituitarism before the study began. Einaudi et al. only performed stimulation tests in subjects with height velocities below the $25^{\text {th }}$ percentile or low basal cortisol levels. ${ }^{9}$ 
In our study, we found no significant differences between normal and abnormal endocrine groups in terms of age at injury, age at study, or TBI severity. To date, associations between TBI severity and hypopituitarism observed in some cross-sectional studies ${ }^{34}$ have not been substantiated in prospective ${ }^{35}$ or paediatric studies. ${ }^{8,9}$ We were unable to substantiate any link between the head injury characteristics evaluated and endocrine outcome. Other studies have identified basal skull fracture, diffuse axonal injury, raised intracranial pressure and prolonged intensive care admissions as risk factors for post-traumatic hypopituitarism. ${ }^{3}$

This study has some limitations. We recruited only $25 \%$ of all eligible subjects, a rate comparable with other retrospective paediatric TBI studies. ${ }^{7,89}$ Relatively few TBI survivors with severe disability were recruited. Whilst the sample recruited was grossly representative of the wider cohort, recruited families were presumably more motivated to seek evaluation than non-responders. Conversely, parents of children with residual disability following TBI might have been reluctant to volunteer them for the study. Excluding subjects with small extradural or subdural haemorrhages, GCS scores of 13-15 and no requirement for ventilation or neurosurgery on ethical grounds could have introduced further selection bias. Although post-traumatic hypopituitarism has been described in children following minor $\mathrm{TBI}^{2,8,9}$ we could not be sure that the benefits of stimulation testing outweighed the risks in this group. A further limitation of the study is that height velocity was only evaluated in subjects with suboptimal GH responses, although height SDS gave no cause for concern in any subject. We considered that it was neither necessary nor practical to recall subjects with normal GH responses and normal height SDS for follow-up height measurements owing to their scattered geographical distribution.

In conclusion, no clinically significant endocrinopathy was identified amongst survivors of accidental childhood TBI evaluated at one to eight years post-injury, although minor abnormalities of the pituitary axes were observed. Growth and development should be monitored in survivors of childhood TBI but we do not consider that our findings justify 


\section{References}

\footnotetext{
${ }^{1}$ Benvenga, S., Campenni, A., Ruggeri, R.M., Trimarchi, F. (2000) Hypopituitarism secondary to head trauma. J Clin Endo Metab, 85, 1353-1361

${ }^{2}$ Acerini, C.L. \& Tasker, R.C. (2008) Neuroendocrine consequences of traumatic brain injury. JPEM, 21, 611-619
}

${ }^{3}$ Schneider, H.J., Kreitschmann-Andermahr, I,. Ghigo, E., Stalla, G.K., Agha, A. (2007) Hypothalamopituitary dysfunction following traumatic brain injury and aneurysmal subarachnoid hemorrhage: a systematic review. JAMA, 298, 1429-1438.

${ }^{4}$ Bondanelli, M., Ambrosio, M.R., Cavazzini, L., Bertocchi, A., Zatelli, M.C., Carli, A., Valle, D., Basaglia, N., Degli Uberti, E.C. (2007) Anterior pituitary function may predict functional and cognitive outcome in patients with traumatic brain injury undergoing rehabilitation. J Neurotrauma, 24, 16871697.

${ }^{5}$ Ghigo, E., Masel, B., Aimaretti, G., Leon-Carrion, J., Casanueva, F.F., Dominguez-Morales, M.R., Elovic, E., Perrone, K., Stalla, G., Thompson, C., Urban, R. (2005) Consensus guidelines on screening for hypopituitarism following traumatic brain injury. Brain Injury, 19, 711-724.

${ }^{6}$ Ho, K.K.Y., on behalf of the 2007 GH Deficiency Consensus Workshop Participants. (2007) Consensus guidelines for the diagnosis and treatment of adults with GH deficiency II: a statement of the GH Research Society in association with the European Society for Pediatric Endocrinology, Lawson Wilkins Society, European Society of Endocrinology, Japan Endocrine Society and the Endocrine Society of Australia. Eur J Endocrinol, 157, 695-700.

${ }^{7}$ Poomthavorn, P., Maixner, W., Zacharin, M. (2008) Pituitary function in paediatric survivors of severe traumatic brain injury. Arch Dis Child, 93, 133-137.

${ }^{8}$ Niederland, T., Makovi, H., Gal, V., Andreka, B., Abraham, C.S., Kovacs, J. (2007) Abnormalities of pituitary function after traumatic brain injury in children. $J$ Neurotrauma, 24, 119-127.

${ }^{9}$ Einaudi, S., Matarazzo, P., Peretta, P., Grossetti, R., Giordano, F., Altare, F., Bondone, C., Andreo, M., Ivani, G., Genitori, L., de Sanctis, C. (2006) Hypothalamo-hypophysial dysfunction after traumatic brain injury in children and adolescents: a preliminary retrospective and prospective study. $J$ Pediatric Endocrinology, 19, 691-703.

${ }^{10}$ Teasdale, G., Jennett, B. (1974) Assessment of coma and impaired consciousness. A practical scale. Lancet, 2, 81-84. 
${ }^{11}$ Baker, S.P., O'Neill, B., Haddon, W. Jr., Long, W.B. (1974) The Injury Severity Score: a method for describing patients with multiple injuries and evaluating emergency care. J Trauma-Injury Infection \& Critical Care, 14, 187-196.

${ }^{12}$ Marshall, L.F., Marshall, S.B., Klauber, M.R., van Berkum, M., Eisenberg, H.M., Jane, J.A., Luerssen, T.G., Marmarou, A., Foulkes, M.A. (1991) A new classification of head injury based on computerised tomography. J Neurosurgery, 75, S14-S20.

${ }^{13}$ Crouchman, M., Rossiter, L., Colaco, T., Forsyth, R. (2001) A practical outcome scale for pediatric head injury. Arch Dis Child, 84, 120-124.

${ }^{14}$ Tanner, J.M., Whitehouse, R.H. (1976) Clinical longitudinal standards for height, weight, height velocity, weight velocity and stages of puberty. Arch Dis Child 51,170-179

${ }^{15}$ Freeman, J.V., Cole, T. J., Chinn, S., Jones, P. R. M., White, E. M. and Preece, M. A. (1995) Cross sectional stature and weight reference curves for the UK, 1990. Arch Dis Child 73, 17-24

${ }^{16}$ Cole, T. J., Freeman, J. V. and Preece, M. A. (1995) Body Mass Index reference curves for the UK, 1990. Arch Dis Child 73, 25-29

${ }^{17}$ Zevenhuijzen, H., Kelnar, C.J.H., Crofton, P.M. (2004) Diagnostic utility of a low-dose gonadotropin-releasing hormone test in the context of puberty disorders. Horm Res, 62, 168-176.

${ }^{18}$ Brabant, G., von zur Mühlen, A., Wüster, C., Ranke, M.B., Kratzsch, J., Kiess, W., Ketelslegers, J.M., Wilhelmsen, L., Hulthén, L., Saller, B., Mattsson, A., Wilde, J., Schemer, R., Kann, P., German KIMS Board. (2003) Serum insulin-like growth factor I reference values for an automated chemiluminescence immunoassay system: results from a multicenter study. Horm Res, 60, 53-60.

${ }^{19}$ Crofton, P.M., Don-Wauchope, A.C., Bath, L.B., Kelnar, C.J. (2004) Cortisol responses to the insulin hypoglycaemia test in children. Horm Res, 61, 92-97.

${ }^{20}$ Agha, A., Rogers, B., Mylotte, D., Taleb, F., Tormey, W., Phillips, J., Thompson, C.J. (2004) Neuroendocrine dysfunction in the acute phase of traumatic brain injury. Clin Endocrinol, 60, 584-591.

${ }^{21}$ National Institute for Health and Clinical Excellence. (2003) Technology Appraisal No. 64. Human growth hormone (somatropin) in adults with growth hormone deficiency.

${ }^{22}$ Clayton, P.E., Cuneo, R.C., Juul, A., Monson, J.P., Shalet, S.M., Tauber, M. (2005) Consensus statement on the management of the GH-treated adolescent in the transition to adult care. Eur $J$ Endocrinol, 152, 165-170.

${ }^{23}$ Pfeifer, M., Kanc, K., Verhovec, R., Kocijancic, A. (2001) Reproducibility of the insulin tolerance test (ITT) for assessment of growth hormone and cortisol secretion in normal and hypopituitary adult men. Clin Endocrinol (Oxf), 54, 17-22

${ }^{24}$ Reynolds, R.M., Stewart, P.M., Seckl, J.R., Padfield, P.L. (2006) Assessing the HPA axis in patients with pituitary disease: a UK survey. Clin Endocrinol, 64, 82-85.

${ }^{25}$ Agha, A., Liew, A., Finucane, F., Baker, L., O'Kelly, P., Tormey, W., Thompson, C.J. (2004) Conventional glucocorticoid replacement overtreats adult hypopituitary patients with partial ACTH deficiency. Clin Endocrinol, 60, 688-693.

${ }^{26}$ Paisley, A.N., Rowles, S.V., Brandon, D., Trainer, P.J. (2009) A subnormal peak cortisol response to stimulation testing does not predict a subnormal cortisol production rate. J Clin Endo Metab, 94, 17571760 .

${ }^{27}$ Martinez, A.S., Domene, H.M., Ropelato, M.G., Jasper, H.G., Pennisi, P.A., Escobar, M.E., Heinrich, J.J. (2000) Estrogen priming effect on Growth Hormone (GH) provocative test: a useful tool for the diagnosis of GH deficiency. J Clin Endo Metab, 85, 4168-4172. 
${ }^{28}$ Lazar, L., Phillip, M. (2010) Is sex hormone priming in peripubertal children prior to growth hormone stimulation tests still appropriate? Horm Res Paediatr, 73, 299-302

${ }^{29}$ Aimaretti, G., Baffoni, C., DiVito, L., Bellone, S., Grottoli, S., Maccario, M., Arvat, E., Camanni, F., Ghigo, E. (2000) Comparisons among old and new provocative tests of GH secretion in 178 normal adults. Eur J Endocrinol, 142, 347-352

${ }^{30}$ Sizonenko, P.C., Clayton, P.E., Cohen, P., Hintz, R.L., Tanaka, T., Laron, Z. (2001) Diagnosis and management of growth hormone deficiency in childhood and adolescence. Part 1: Diagnosis of growth hormone deficiency. Growth Horm IGF Res, 11, 137-165.

${ }^{31}$ Ghigo, E., Bellone, J., Aimaretti, G., Bellone, S., Loche, S., Cappa, M., Bartolotta, E., Dammacco, F., Camanni, F. (1996) Reliability of provocative tests to assess growth hormone secretory status. Study in 472 normally growing children. J Clin Endocrinol Metab, 81, 3323-3327.

${ }^{32}$ Amed, S., Delvin, E., Hamilton, J., on behalf of the Canadian Pediatric Endocrine Group. (2008) Variation in growth hormone immunoassays in clinical practice in Canada. Horm Res, 69, 290-294.

${ }^{33}$ Yeste, D., Tomasini, R., Dodino, G., Gussinye, M., Potau, N., Carrascosa, A. (2007)

Hypoglycaemia-insulin test: discordant growth hormone and cortisol response in paediatric patients regarding recovery from hypoglycaemia with or without oral glucose solution. Horm Res, 67, 42-45.

${ }^{34}$ Bondanelli, M., De Marinis, L., Ambrosio, M.R., Monesi, M., Valle, D., Zatelli, M.C., Fusco, A., Bianchi, A., Farneti, M., Degli Uberti, E.C. (2004) Occurrence of pituitary dysfunction following traumatic brain injury. J Neurotrauma, 21, 685-696.

${ }^{35}$ Klose, M., Juul, A., Struck, J., Morgenthaler, N.G., Kosteljanetz, M., Feldt-Rasmussen, U. (2007) Acute and long-term pituitary insufficiency in traumatic brain injury: a prospective single-centre study. Clin Endocrinol, 67, 598- 606. 
Figure 1: Flow diagram of subject recruitment

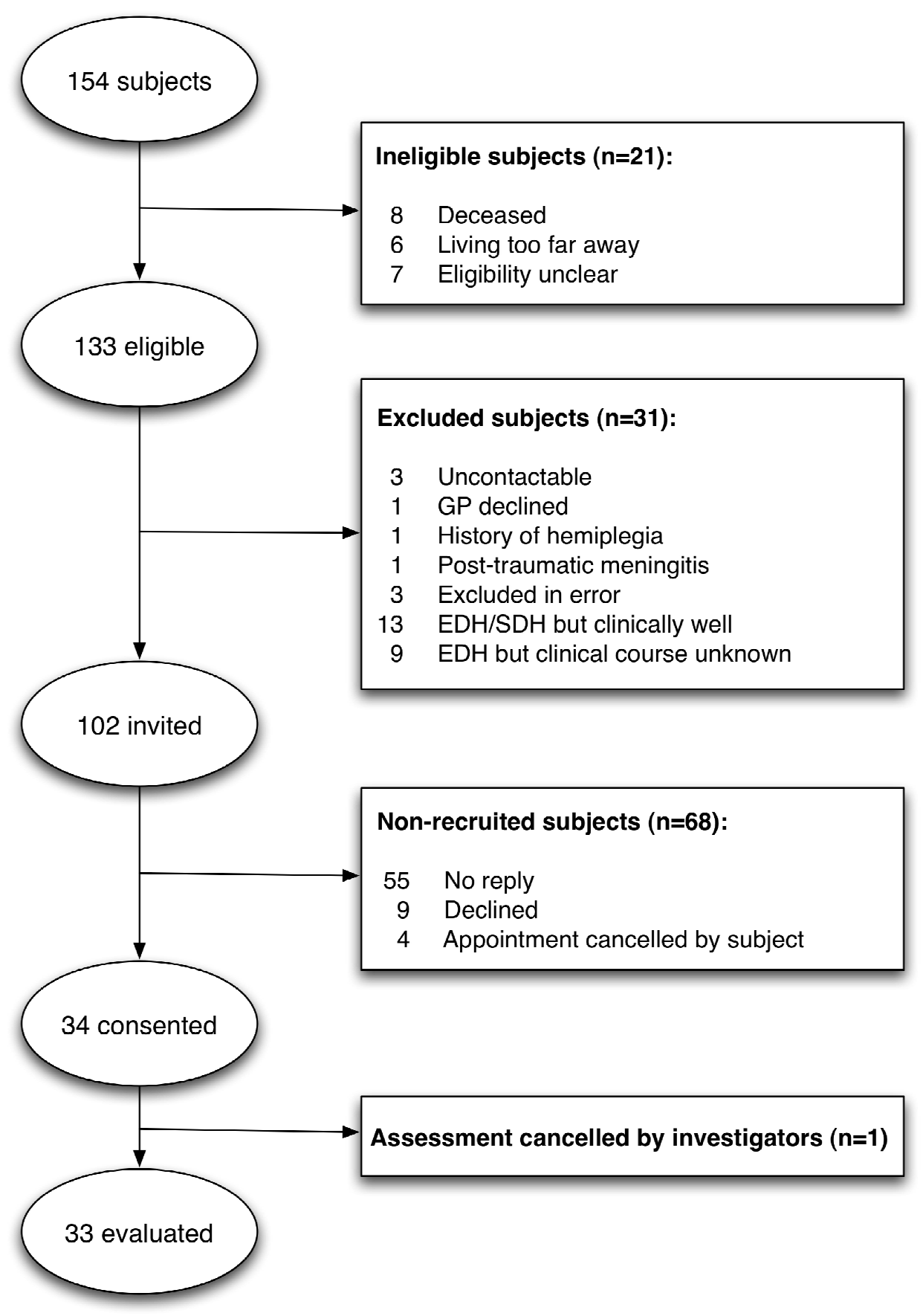

GP, general practitioner; EDH, extradural haemorrhage; $\mathrm{SDH}$, subdural haemorrhage 
Figure 2A: Cortisol responses to stimulation testing

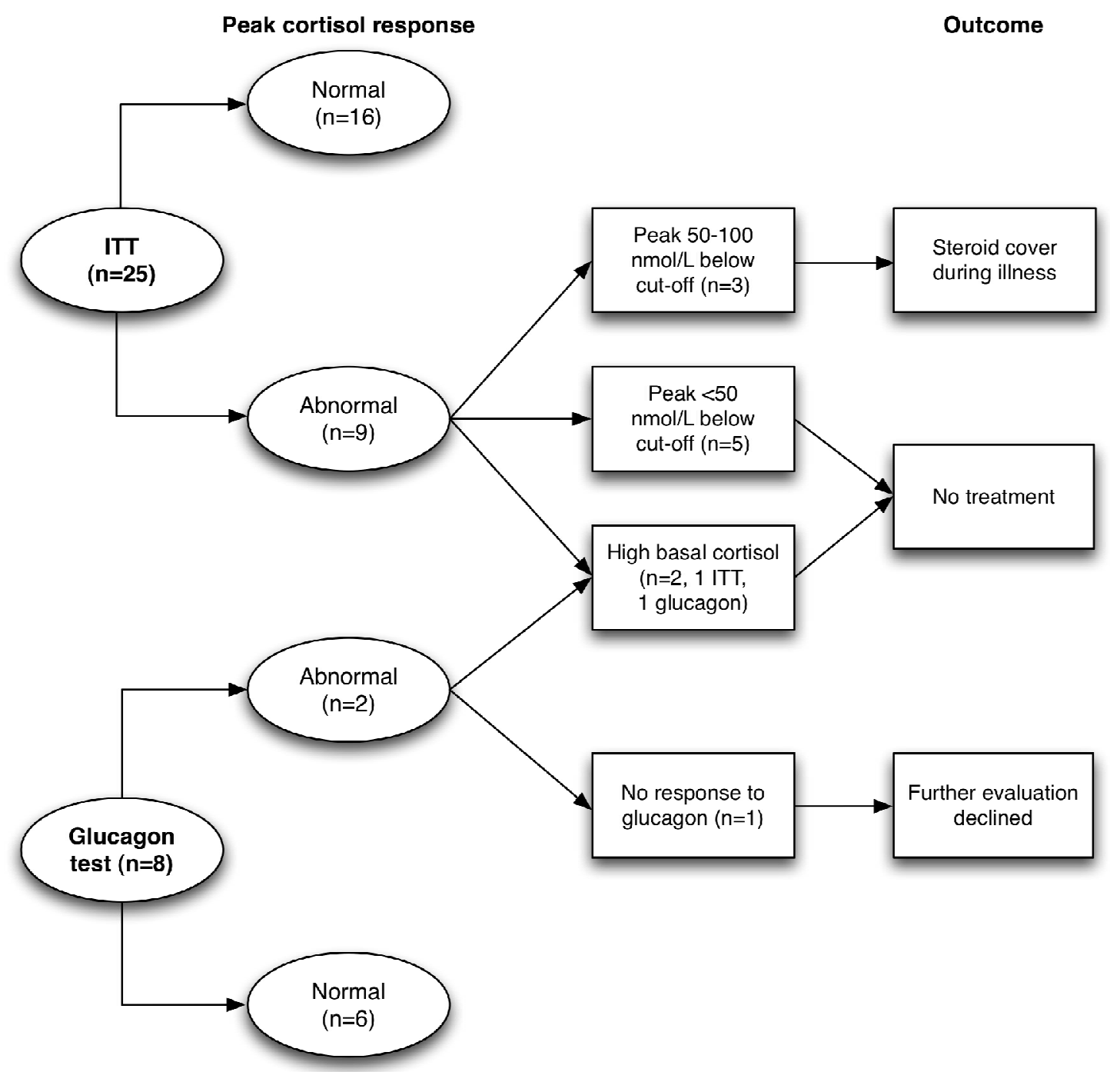


Figure 2B: $\mathrm{GH}$ responses to stimulation testing

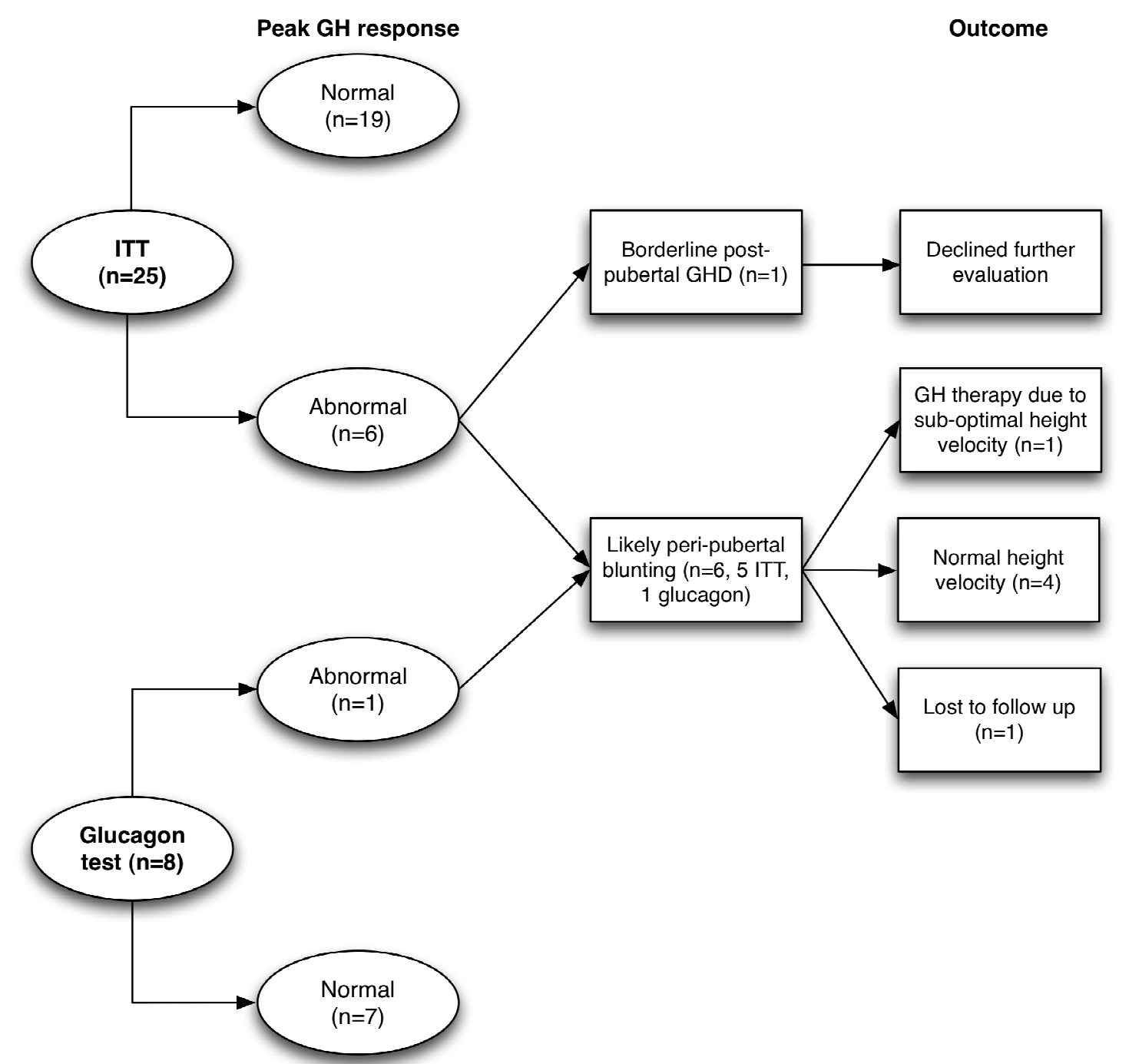


Table 1: Subject characteristics $(n=33)$

\section{Characteristic}

Gender (male / female)

Age at study (years)

Age at injury (years)

Interval since injury (years)

TBI severity (minor / moderate / severe)

$\mathrm{KOSCHI}$ score at study (good outcome / moderate disability / severe disability)

Pubertal status at study (pre- / early or mid- / late or post-)

Height SDS at study**

Weight SDS at study**

BMI SDS at study**

${ }^{*}$ All mean (range) except for interval since injury, which is expressed as median (range)

$4.1(1.4-7.8)$

$15 / 16 / 2$

\section{$\mathrm{N}$, or mean/median* (range)}

$25 / 8$

$13.4(5.4-21.7)$

$9.2(0.6-14.1)$

$6 / 15 / 12$

$10 / 7 / 16$

$0.50(-1.57-+3.00)$

$0.65(-1.28-+2.86)$

$0.67(-1.01-+2.92)$

${ }^{* *}$ Excluding data for one subject on supra-physiological corticosteroid therapy. 
Table 2: Subjects with abnormal pituitary hormone results

\begin{tabular}{|c|c|c|c|c|c|c|c|}
\hline No. & Sex & $\begin{array}{c}\text { TBI } \\
\text { severity }\end{array}$ & $\begin{array}{c}\text { Age } \\
\text { (years) } \\
\text { at study }\end{array}$ & $\begin{array}{l}\text { Height } \\
\text { SDS }\end{array}$ & $\begin{array}{l}\text { Pubertal } \\
\text { stage }\end{array}$ & $\begin{array}{c}\text { GH/HPA } \\
\text { stimulation } \\
\text { test used }\end{array}$ & $\begin{array}{c}\text { Hormone } \\
\text { axis affected }\end{array}$ \\
\hline 1 & $M$ & Severe & 16.4 & 0.64 & Late/post- & ITT & $\mathrm{HPA}^{1}$ \\
\hline 2 & M & Severe & 17.2 & 0.56 & Late/post- & ITT & $\mathrm{HPA}^{1}$ \\
\hline 3 & $M$ & Severe & 17.0 & -0.93 & Late/post- & ITT & $\mathrm{GH}$ \\
\hline 4 & $M$ & Moderate & 9.8 & 1.38 & Pre- & Glucagon & $\mathrm{GH}$ \\
\hline 5 & $M$ & Moderate & 9.0 & 0.10 & Pre- & ITT & PRL \& HPA ${ }^{1}$ \\
\hline 6 & $M$ & Moderate & 12.0 & 1.30 & Early/mid- & ITT & $\mathrm{GH} \& \mathrm{HPA}^{2}$ \\
\hline 7 & $M$ & Moderate & 11.1 & 0.75 & Pre- & ITT & $\mathrm{GH}$ \\
\hline 8 & $M$ & Moderate & 15.1 & 0.90 & Late/post- & Glucagon & HPA \\
\hline 9 & $M$ & Moderate & 14.8 & -1.52 & Early/mid- & ITT & $\mathrm{GH} \& \mathrm{HPA}^{1,3}$ \\
\hline 10 & M & Moderate & 12.9 & 1.00 & Early/mid- & ITT & $G H \& H P A^{2}$ \\
\hline 11 & M & Minor & 12.9 & 0.23 & Early/mid- & ITT & $\mathrm{HPA}^{1}$ \\
\hline 12 & $M$ & Minor & 8.5 & -0.31 & Pre- & ITT & $\mathrm{GH}$ \\
\hline 13 & $\mathrm{~F}$ & Moderate & 15.3 & 0.66 & Late/post- & ITT & $\mathrm{HPA}^{2,3}$ \\
\hline
\end{tabular}

